\title{
HUBUNGAN PAPARAN DEBU DAN MASA KERJA DENGAN KELUHAN PERNAFASAN PADA TENAGA KERJA CV. JIYO'G KONVEKSI DESA NOTOG KECAMATAN PATIKRAJA KABUPATEN BANYUMAS TAHUN 2017
}

\author{
Mahfud Subarkah $^{*}$, Budi Triyantoro ${ }^{* *}$, Khomsatun $^{* * *}$ ) \\ Jurusan Kesehatan Lingkungan, Politeknik Kesehatan Kemenkes Semarang, \\ Jl.Raya Baturaden KM 12 Purwokerto, Indonesia
}

\begin{abstract}
Abstrak
Perkembangan industri saat ini semakin maju dan terus menerus mengalami peningkatan yang begitu pesat baik bidang komunikasi, teknologi, pertanian, bahan bangunan maupun yang bergerak pada industri tekstil.Industri konveksi banyak menghasilkan debu, diantaranya debu organik yaitu debu katun atau kapas.Paparan dari debu organik dapat menimbulkan gangguan keluhan saluran pernafasan.Tujuan penelitian ini adalah menganalisis hubungan paparan debu dan masa kerja dengan keluhan pernafasan pada tenaga kerja CV. Jiyo'g Konveksi Desa Notog Kecamatan Patikraja Kabupaten Banyumas. Jenis penelitian ini menggunakan metode pendekatan cross sectional. Uji statistik yang dipakai adalah regresi logistik.Sampel dalam penelitian ini adalah 10 orang menggunakan sampling jenuh dengan kriteria inklusi yaitu laki-laki. Data diperoleh dengan cara membagikan kuesioner kepada responden dan pengukuran paparan debu, kelembaban dan kecepatan angin. Hasil pengukuran paparan debu di CV. Jiyo'g Konveksi rata-rata adalah 0,066 mg/m3. Hasil tersebut tidak melebihi $N A B(0,2 \mathrm{mg} / \mathrm{m} 3)$ sesuai Permenkes RI Nomor. 70 Tahun 2016 tentang Standar dan Persyaratan Kesehatan Lingkungan Kerja Industri untuk kategori debu katun/ kapas. Rata-rata masa kerja pada tenaga kerja adalah 12,3 tahun. Hasil observasi keluhan pernafasan terhadap pekerja didapatkan 3 pekerja memiliki keluhan pernafasan dan 7 pekerja tidak memiliki keluhan pernafasan. Hasil uji statistik paparan debu dan keluhan pernafasan pada pekerja diperoleh nilai sig. 0,459 (> 0,05), untuk masa kerja dan keluhan pernafasan pada pekerja diperoleh nilai sig. 0,129 (>0,05). Disimpulkan bahwa tidak ada hubungan antara paparan debu dan masa kerja dengan keluhan pernafasan di CV. Jiyo'g Konveksi Desa Notog Kecamatan Patikraja Kabupaten Banyumas.Disarankan kepada tenaga kerja agar mengurangi paparan debu dengan pemakaian masker dan mengurangi kebiasaan merokok.

Kata kunci:debu; keluhan pernafasan; masa kerja; kesehatan lingkungan
\end{abstract}

\begin{abstract}
The development of industries was increasingly progressed and continuously experiencing rapid improvement in the field of communication, technology, agriculture, building materials as well as engaged in the textile industry. Convection of industry produces a lot of dust, including organic dust that is cotton or cotton dust. Exposure to any amount of organic dust may cause respiratory symptoms. The main objective of this research was to analyze relationships of dust exposure and working period with respiratory symptoms of workers at CV. Jiyo'g Konveksi in the Notog Village, Subdistrict of Patikraja, District of Banyumas in 2017.The type of research in this essay was using cross-sectional approach. The analysis technique used is logistic regression. The research sample was 10 with saturated sampling technique also Inclusion criteria which is male. Data was obtained by distributing the respondents a questionaries and then measuring the dust exposure, humidity, also a wind speed.The measurements results at CV. Jiyo'g Konveksi show that the average of dust exposure levels is $0,066 \mathrm{mg} / \mathrm{m} 3$. The result isn't exceeding the threshold limit value for $(0,2 \mathrm{mg} / \mathrm{m} 3)$ according to government regulation health republic of Indonesia Number 70 of 2016 says health of industy and work environment standard for cotton dust category. The Average of working periode on the workers is 12,5 years. The observation result of respiratory simptoms to
\end{abstract}

\footnotetext{
${ }^{*}$ E-mail: kakahdaijiro74@gmail.com

${ }^{* * *}$ E-mail: buditri1309@gmail.com

${ }^{* * *}$ E-mail: khomsatun1962@gmail.com
} 
workers is 3 a worker got an respiratory simptoms and 7 who doesn't got an respiratory simptoms. The statistics test result from dust exposure and respiratory simptoms to a workers got sig. 0,459 (>0,05), then for working period and respiratory simptoms to a workers the result is sig. 0,129 (>0,05).Concluded that there's not the relationship between dust exposure and working periode with respiratory sympotoms at CV. Jiyo'g Konveksi in Notog Village, Subdistrict of Patikraja, District of Banyumas in 2017. Recommended for a workers to reduce the dust exposure using a cloth mask and also Reduce smoking habits.

Keywords:dust; exposure of dust;working period, environmental health

Pendahuluan: Undang-undang Republik Indonesia Nomor 36 tahun 2009 tentang Kesehatan pada Bab XII pasal 164 mengenai Kesehatan Kerja menyatakan bahwa upaya kesehatan kerja ditujukan untuk melindungi pekerja agar hidup sehat dan terbebas dari gangguan kesehatan serta pengaruh buruk yang diakibatkan oleh pekerjaan. Setiap tenaga kerja di industri harus memperoleh perlindungan diri dari berbagai persoalan di sekitar tempat kerjanya dan hal-hal yang dapat menimpa dirinya atau mengganggu dalam pelaksanaan tugasnya sehari-hari.

Perkembangan industri saat ini semakin maju dan terus menerus mengalami peningkatan yang begitu pesat baik bidang komunikasi, teknologi, pertanian, bahan bangunan maupun yang bergerak pada industri tekstil. Kemajuan industri satu pihak sangat menguntungkan, tetapi lain pihak dapat menimbulkan pengaruh buruk terhadap kesehatan tenaga kerja. Dampak pengaruh buruk inilah yang mengganggu proses bekerja pada tenaga kerja, sehingga perlu adanya intervensi guna mengoptimalkan kinerja yang aman, dibutuhkanlah perlindungan tenaga kerja.

Para pekerja perlu mendapatkan kesehatan kerja yang baik, karena kesehatan kerja bertujuan untuk meningkatkan dan memelihara derajat kesehatan fisik, mental dan sosial yang setinggi-tingginya bagi pekerja di semua tempat pekerjaan.Pembinaan lingkungan kerja yang sehat memenuhi syarat kesehatan, penyelenggaraan upaya kesehatan tenaga kerja dan pengaturan syarat-syarat kesehatan bagi tenaga kerja (Nuraini, 2012).Salah satu faktor utama yang harus diperhatikan dalam kesehatan bagi tenaga kerja, yaitu; kualitas udara, kualitas udara dipengaruhi oleh banyak hal, salah satunya adalah polutan.Polutan dapat berasal dari pembakaran, pemanasan, kegiatan transportasi, dan industri. Polutan tersebut sebagian akan tertinggal di udara dan mempengaruhi kualitas lingkungan di sekitarnya, sedangkan sebagian lain akan terbawa angin, zat pencemar yang dikeluarkan dari polutan diantaranya, yaitu debu (Department for Environmental Food \& Rural Affairs, 2014).

Produktifitas dan kualitas kerja sangat dipengaruhi oleh debu, karena debu merupakan salah satu faktor yang berhubungan dengan kecelakaan kerja. Debu termasuk partikel solid yang terdapat di udara dengan berbagai ukuran tergantung dari asal kadar debu, karakteristik kadar debu dan kondisi lingkungan. Selain itu partikelkadar debu yang terhirup oleh tenaga kerja dapat menimbulkan kelainan fungsi atau kapasitas paru, kelainan tersebut dapat terjadi akibat rusaknya jaringan paru-paru akibat kerja disebabkan oleh paparan debu langsung terhadap pekerja (Depkes RI, 2003).

Kondisi inilah yang membuat partikel debu menjadi bahaya yang dapat menyebabkan pengurangan kenyamanan kerja, gangguan pernafasan, gangguan fungsi faal paru bahkan dapat menimbulkan keracunan umum.(Suma"mur P.K., 1996:70). Semakin lama seseorang dalam bekerja, maka semakin banyak dia telah terpapar bahaya yang ditimbulkan oleh lingkungan kerja, dan apabila alveoli mengeras, akibatnya mengurangi elastisitas dalam menampung volume udara hingga kemampuan mengikat Oksigen menurun, sehingga dapat menurunkan kapasitas vital paru (Depkes RI, 2003:95).

Pekerja yang bekerja di industri tekstil, selalu terpapar langsung debu lingkungan kerjanya.Pemaparan debu menimbulkan kelainan paru tenaga kerja. Salah satu industri teksil yang berupaya memenuhi kebutuhan sandang yang dalam proses kerjanya menghasilkan paparan debu tidak lain, yaitu; industri konveksi. Industri konveksi terdapat faktor bahaya yang dapat mengganggu kesehatan tenaga kerja, berupa paparan debu serat kain, kapas, asap mesin sablon, paparan panas, dan bau cat. Partikel debu yang terdapat dari bahan tekstil dapat menyebabkan kerusakan paru dan fibrosis bila terinhalasi selama bekerja terus menerus. Dalam melakukan proses produksi, kadar debu kapas total yang dihasilkan tidak boleh lebih dari Nilai Ambang Batas (NAB) yaitu 0,2 mg/m3 menurut SNI 19-0232-2005 tentang Nilai Ambang Batas Zat Kimia di Udara Tempat Kerja.

Industri tekstil CV. Jiyo'g Koveksi yang berada di Desa Notog, Kecamatan Patikraja, Kabupaten Banyumas ini merupakan salah satu home industri yang berbasis pada swasembada sandang yang aktivitas kerjanya selalu menghasilkan debu. Terdapat 5 proses produksi antara lain; pemotongan bahan, penyablonan, pengobrasan, penjahitan, setrika. Dampak paparan debu di CV. Jiyo'g konveksi terhadap para pekerja sangat berpotensi, yaitu dari semua tahap proses produksi mengeluarkan debu. Debu serat kain dan tumpukan bahan siap proses, ruangan tata letak yang sempit dan 
juga bangunan gedung yang berdekatan dengan jalan raya menimbulkan paparan debu langsung masuk ke industri yang dapat mengancam kesehatan tenaga kerja.

Hasil survei pendahuluan yang telah dilakukan yaitu dengan wawancara di CV Jiyo'g Konveksi Notog, tenaga kerja disana ada 20 orang.Ada beberapa pekerja yang berisiko terkena paparan debu langsung diantaranya karena terdapat keluhan dari bebrapa pekerja yang mengalami sesak napas, sakit dada, batuk, dan tenggorokkan sakit. Para tenaga kerja yang bekerja $8 \mathrm{jam} /$ hari (08.00-16.00 WIB) dan istirahat pada pukul 12.00-13.00 WIB tersebut, dan kemungkinan mayoritas para pekerja menghirup debu dari serat debu tekstil kain pakaian.

Pengamatan yang telah dilakukan peneliti pada kenyataannya sebagian besar pekerja masih belum menyadari pentingnya penggunaan masker saat bekerja.Pertimbangan uraian latar belakang diatas, peneliti tertarik menjadikan penelitian dengan judul "Hubungan Paparan Debu dan Masa Kerja dengan Keluhan Pernafasan pada Tenaga Kerja CV. Jiyo'g Konveksi Desa Notog Kecamatan Patikraja Kabupaten Banyumas 2017”.

Perumusan masalah :Adakah hubungan paparan debu dan masa kerja dengan keluhan pernafasan pada tenaga kerja CV. Jiyo'g Konveksi Desa Notog Kecamatan Patikraja Kabupaten Banyumas?

Tujuan dari penelitian ini adalah :Mengukur paparan debu pada pekerja di CV. Jiyo'g Konveksi Desa Notog Kecamatan Patikraja Kabupaten Banyumas.

Mengetahui masa kerja pada pekerja CV. Jiyo'g Konveksi Desa Notog Kecamatan Patikraja Kabupaten Banyumas.

Mendeskripsikan keluhan pernafasan pada pekerja di CV. Jiyo'g Konveksi.

Mengukur suhu dan kelembaban di CV. Jiyo'g Konveksi.

Menganalisis hubungan paparan debu dan masa kerja dengan keluhan pernafasan pada tenaga kerja CV. Jiyo'g Konveksi Desa Notog Kecamatan Patikraja Kabupaten Banyumas.

Tinjauan Pustaka:Pengertian pencemaran lingkungan berdasarkan Undang-undang Nomor 32 Tahun 2009 tentang Perlindungan dan Pengelolaan Lingkungan Hidup menjelaskan :

“.........Pencemaran lingkungan hidup adalah masuk atau dimasukkannya makhluk hidup, zat, energi, dan atau komponen lain ke dalam lingkungan hidup oleh kegiatan manusia sehingga melampaui baku mutu lingkungan hidup yang telah ditetapkan.”

Pencemaran lingkungan berdasarkan pasal 1 angka 7 Undang-undang RI No. 4 Tahun 1982, menjelaskan :

“.........Pencemaran lingkungan adalah masuknya atau dimasukannya makhluk hidup, zat, energi, dan atau komponen lain ke dalam lingkungan dan atau berubahnya tatanan lingkungan oleh kegiatan manusia atau proses alam, sehingga kualitas lingkungan turun sampai ke tingkat tertentu yang menyebabkan lingkungan menjadi kurang atau tidak dapat berfungsi lagi sesuai dengan peruntukannya.”

Pencemaran udara adalah masuknya atau dimasukkannya zat, energi, dan atau komponen lain ke dalam udara ambien oleh kegiatan manusia, sehingga mutu udara ambien turun sampai ke tingkat tertentu yang menyebabkan udara ambien tidak dapat memenuhi fungsinya. (PP RI No.41 Tahun 1999 tentang Pengendalian Pencemaran Udara).

Menurut Chambers (1976 : 13 -14) dan Master (1991 : 270) (Mukono, 1997, h. 6 ); Pencemaran udara adalah bertambahnya bahan atau substrat fisik atau kimia ke dalam lingkungan udara normal yang mencapai sejumlah tertentu, sehingga dapat di deteksi oleh manusia ( atau dihitung atau diukur ) serta dapat memberikan efek pada manusia, binatang, vegetasi dan material.

Pengertian debu yang didefinisikan menurut (Suma'mur, 2009) menjelaskan :

“.........Debu adalah partikel zat padat yang dihasilkan oleh kekuatan alami atau mekanik, seperti pada pengolahan, penghancuran, pelembutan, pengepakan yang cepat, peledakan dan lain-lain. Dari bahan organik maupun anorganik, misalnya: kapas, kayu, batu, biji logam, arang batu, butir-butir zat dan sebagainya. Sifat debu ini tidak berflokulasi kecuali oleh gaya tarikan elektris, tidak berdifusi dan turun oleh gaya tarik bumi."

Pengertian debu menurut (Sugeng Budiono. 2001:106) men-jelaskan :

“.........Debu adalah partikel zat padat, yang disebabkan oleh kekuatan alami atau mekanis seperti pengolahan, penghancuran, peledakan, dan lainnya.Bahan yang organik maupun anorganik, misalnya batu, butiran zat, dan lainnya."

Menurut Departemen Kesehatan RI yang dikutip oleh Sitepu (2002), partikel debu di udara mempunyai sifat:

Sifat pengendapan adalah sifat debu yang cenderung selalu mengendap karena gaya gravitasi bumi. Tetapi karena kecilnya ukuran debu, kadang- kadang debu ini relatif tetap berada di udara.

Sifat permukaan basah adalah sifat permukaan debu cenderung selalu basah, dilapisi oleh lapisan air yang sangat tipis.Sifat ini penting dalam pengendalian debu dalam tempat kerja.

Sifat penggumpalan yaitu, Oleh karena permukaan debu selalu basah, sehingga dapat menempel satu sama lain dan dapat menggumpal. Turbulensi udara meningkatkan pembentukan penggumpalan debu.Kelembaban di bawah saturasi, kecil pengaruhnya terhadap penggumpalan debu.Kelembaban yang melebihi tingkat 
huminitas di atas titik saturasi mempermudah penggumpalan debu. Oleh karena itu partikel debu bias merupakan inti dari pada air yang berkonsentrasi sehingga partikel menjadi besar.

Sifat listrik statis adalah Debu mempunyai sifat listrik statis yang dapat menarik partikel lain yang berlawanan. Dengan demikian, partikel dalam larutan debu mempercepat terjadinya proses penggumpalan.

Sifar optis adalah Debu atau partikel basah atau lembab lainnya dapat memancarkan sinar yang dapat terlihat dalam kamar gelap.

Secara garis besar debu dapat dibagi atas 3 macam yaitu:

Debu organik yaitu seperti debu kapas, debu daun daunan, tembakau dan sebagainya.

Debu Mineral yaitu merupakan senyawa komplek: SiO2, SiO3, arang batu dan lain- lain.

Debu Metal yaitu debu yang mengandung unsur logam: $\mathrm{Pb}, \mathrm{Hg}, \mathrm{Cd}$, Arsen, dll.

Infeksi Saluran Pernafasan Akut (ISPA) adalah penyakit infeksi akut yang menyerang salah satu bagian atau lebih dari saluran nafas mulai dari hidung hingga kantong paru (alveoli) termasuk jaringan adneksanya seperti sinus/rongga di sekitar hidung (sinus para nasal), rongga telinga tengah dan pleura (Depkes, 2009).

Keluhan pernapasan yang terjadi dipengaruhi oleh ukuran debu. Debu yang berukuran 5-10 mikron akan masuk ke dalam saluran napas atas, 3-5 mikron masuk ke dalam saluran napas tengah, 1-3 mikron dapat mencapai pembuluh di alveoli, 0,5-1 mikron akan menempel di alveoli, dan debu yang berukuran 0,1-0,5 akan melayang di atas alveoli (Depkes, 2014). Berbagai keluhan seperti hidung tersumbat, batuk, rinitis, dan asma juga dapat dialami oleh pekerja di industri kayu (Mirza, 2010).

Menurut Mukono (2008, h. 10), banyak faktor yang mempengaruhi pencemaran udara, antara lain :

Suhu udara dapat mempengaruhi konsentrasi pencemaran udara (debu) sesuai dengan keadaan cuaca tertentu. Suhu udara yang tinggi menyebabkan udara semakin renggang sehingga konsentrasi pencemar menjadi semakin rendah. Sebaliknya pada suhu yang dingin keadaan udara makin padat sehingga konsentrasi pencemar diudara semakin tinggi. Menurut Keputusan Menteri Kesehatan Nomor 1405/ Menkes/ SK/ XI/ 2002 tentang persyaratan dan tata cara penyelenggaraan kesehatan lingkungan kerja industri untuk suhu udara sebesar $18^{\circ} \mathrm{C}-30^{\circ} \mathrm{C}$.

Kelembaban udara juga dapat mempengaruhi konsentrasi debu di udara. Pada kelembaban yang tinggi maka kadar uap air di udara dapat bereaksi dengan pencemar udara menjadi zat lain yang tidak berbahaya atau pencemar sekunder. Keputusan Menteri Kesehatan Nomor 1405/ Menkes/ SK/ XI/ 2002 tentang persyaratan dan tata cara penyelenggaraan kesehatan lingkungan kerja industri untuk kelembaban udara sebesar 65\%-95\%.

Akibat pergerakan udara maka akan terjadi suatu proses penyebaran yang dapat mengakibatkan pencemaran dari bahan pencemar udara, sehingga kadar suatu pencemar pada jarak tertentu dari sumber akan mempunyai kadar yang berbeda. Berdasarkan Keputusan Menteri Kesehatan Nomor 1405/ Menkes/ SK/ XI/ 2002 tentang persyaratan dan tata cara penyelenggaraan kesehatan lingkungan kerja industri untuk kecepatan angin berkisar antara 0,15 m/s - 0,25 m/s.

Faktor yang mempengaruhi gangguan pernafasan pekerja:

Usia berhubungan dengan proses penuaan atau bertambahnya umur. Semakin tua usia seseorang, maka semakin besar kemungkinan terjadi penurunan kapasitas fungsi paru (Suyono, 2001). Kebutuhan zat tenaga terus meningkat sampai akhirnya menurun setelah usia 40 tahun berkurangnya kebutuhan tenaga tersebut dikarenakan telah menurunnya kekuatan fisik.Jangka waktu orang sudah bekerja dari pertama mulai masuk hingga sekarang masih bekerja.Masa kerja dapat diartikan sebagai sepenggal waktu yang agak lama dimana seorang tenaga kerja masuk dalam satu wilayah tempat usaha sampai batas waktu tertentu (Suma'mur P.K., 2009:71).Lama kerja akan mempengaruhi terhadap lama tenaga kerja terpapar bahan pencemar yang ada di lingkungan kerja. Salah satu bahan pencemar tersebut adalah debu.Masa kerja dikategorikan menjadi :

Masa kerja baru ( $<5$ tahun)

Masa kerja lama ( $\geq 5$ tahun)

Semakin lama seseorang dalam bekerja maka semakin banyak dia terpapar bahaya yang ditimbulkan oleh lingkungan kerja tersebut (Suma'mur, 1996, h. 70).

Menurut Suma'mur (2009) anamnesis tentang riwayat penyakit dimaksudkan untuk mengetahui kemungkinan salah satu faktor di tempat kerja, pada pekerjaan atau lingkungan kerja menjadi penyebab penyakit paru akibat kerja.

Pemaparan yang menahun oleh gas dan SPM (Suspended Particulate Matter) mempunyai efek terhadap saluran pernafasan (H.J. Mukono, 2003, h.72). Lama kerja akan terpengaruh terhadap lama pekerja terpapar oleh bahan pencemar yang ada di lingkungan kerjanya. Salah satunya adalah debu.Debu organik dapat menimbulkan fibrosis dan debu anorganik tidak selalu menimbulkan fibrosis jaringan, keadaan tersebut dipengaruhi oleh jumlah dan lama papran. Lama dan singkatnya kemunculan gejala tergantung pada kadar debu di udara, dosis paparan komulatif, serta lamanya debu di dalam paru (detiknews.com/read,2010). Sehingga di sini lama paparan karyawan pada bagian produksi konveksi CV. Jiyo'g Konveksi adalah berapa jam lamanya karyawan terpapar dengan debu dalam sehari dikalikan dengan sudah berapa lama karyawan 
bekerja di bagian produksi konveksi CV. Jiyo'g Konveksi.

Menurut (Niken, 2003) adalah melindungi pernafasan terhadap gas, uap, debu, kabut, atau udara yang terkontaminasi di tempat kerja yang dapat bersifat racun, korosi ataupun rangsangan.

Masker berfungsi untuk melindungi debu atau partikel partikel yang lebih besar yang masuk ke dalam pernafasan, dapat terbuat dari kain dengan pori - pori tertentu.

Respirator berfungsi untuk melindungi pernafasan dari debu, kabut, uap logam, asap dan gas.

Pengukuran kadar debu di udara bertujuan untuk mengetahui kadar debu pada suatu lingkungan kerja berada konsentrasinya sesuai dengan kondisi lingkungan kerja yang aman dan sehat bagi pekerja.

Pengambilan atau pengukuran kadar debu di udara biasanya dilakukan dengan metode gravimetri, yaitu dengan cara menghisap dan melewatkan udara dalam volume tertentu melalui saringan serat gelas/kertas saring. Alat-alat yang biasa digunakan untuk pengambilan sampel debu total (TSP) di udara seperti :

EPAM 5000 Haz Dust, alat ini digunakan untuk mengukur monitoring debu TSP, PM10, PM2.5, PM1.0uM di udara (Indoor/ Outdoor), alat ini menggunakan hamburan cahaya untuk mengukur konsentrasi partikel dan memberikan langsung real time penentuan dan rekaman data konsentrasi partikel udara dalam milligram per-meter3 $(\mathrm{mg} / \mathrm{m} 3)$ dengan kertas saring diameter $47 \mathrm{~mm}$ (100 lembar).

High Volume Air Sampler, alat ini menghisap udara ambien dengan pompa berkecepatan 1,1 - 1,7 m³/menit, partikel debu berdiameter 0,1-10 mikron akan masuk bersama aliran udara melewati saringan dan terkumpul pada permukaan serat gelas. Alat ini dapat digunakan untuk pengambilan contoh udara selama 24 jam, dan bila kandungan partikel debu sangat tinggi maka waktu pengukuran dapat dikurangi menjadi 6 - 8 jam.

Low Volume Air Sampler, Alat ini dapat menangkap debu dengan ukuran sesuai yang kita inginkan dengan cara mengatur flow rate 20 liter/ menit dapat menangkap partikel berukuran 10 mikron. Dengan mengetahui berat kertas saring sebelum dan sesudah pengukuran maka kadar debu dapat dihitung.Personal Dust Sampler, Alat ini biasa digunakan untuk menentukan Respiral Dust (RD) di udara atau debu yang dapat lolos melalui filter bulu hidung manusia selama bernafas. Untuk flow rate 2 liter/menit dapat menangkap debu yang berukuran < 10 mikron.Alat ini biasanya digunakan pada lingkungan kerja dan dipasang pada pinggang pekerja karena ukurannya yang sangat kecil.Udara sangat diperlukan dalam setiap kehidupan manusia.Untuk itu perlu adanya kualitas udara yang baik agar kesehatan manusia tetap terjaga.Ketentuan kualitas udara diatur dalam undang-undang dan peraturanperaturan terkait.

Standar batas-batas pencemaran udara disebut dengan NAB (Nilai Ambang Batas). NAB adalah kadar tertinggi zat dimana seorang dalam suatu lingkungan masih sanggup berada tanpa menunjukan suatu respons berupa penyakit atau gangguan-gangguan terhadap kesehatannya sehari-harinya untuk jangka waktu 8 jam/hari serta 40 jam seminggunya. (Slamet Ryadi,1982, h.95).Nilai Ambang Batas (NAB) Untuk Debu Nilai ambang batas (NAB) adalah standar faktorfaktor lingkungan kerja yang dianjurkan di tempat kerja agar tenaga kerja masih dapat menerimanya tanpa mengakibatkan penyakit atau gangguan kesehatan, dalam pekerjaan sehari-hari untuk waktu tidak melebihi 8 jam sehari atau 40 jam seminggu. Kegunaan NAB ini sebagai rekomendasi pada praktek higiene perusahaan dalam melakukan penatalaksanaan lingkungan kerja sebagai upaya untuk mencegah dampaknya terhadap kesehatan.Adapun kandungan debu maksimal di dalam udara ruangan dalam pengukuran debu rata-rata 8 jam adalah $0,15 \mathrm{mg} / \mathrm{m}^{3}$.Berdasarkan Keputusan Menteri Kesehatan Nomor 1405/ Menkes/ SK/ XI/ 2002 tentang persyaratan dan tata cara penyelenggaraan kesehatan lingkungan kerja industri untuk kandungan debu maksimal di dalam ruangan dalam pengukuran rata-rata 8 jam.

\begin{tabular}{lll}
\hline No. & Jenisdebu & Konsentrasimaksimal \\
\hline 1. & Debutotal & $10 \mathrm{mg} / \mathrm{m}^{3}$ \\
2. & Asbesbebas & 5 serat $/ \mathrm{mludaradenganpanjan}$ \\
3. & Silicattotal & $50 \mathrm{mg} / \mathrm{m}^{3}$
\end{tabular}

Adapun Nilai Ambang Batas untuk debu berdasarkan Permenaker No Per.13/ Men/ X/ 2011 tentang Nilai Ambang Batas Faktor Fisik dan Faktor Kimia di Tempat Kerja kandungan debu maksimal didalam udara ruangan dalam pengukuran debu rata-rata 8 jam adalah $5 \mathrm{mg} / \mathrm{m}^{3}$. Untuk standar debu katun/ kapas menurut Permenkes Nomor. 70 Tahun 2016 tentang Standar dan Persyaratan Kesehatan Lingkungan Kerja Industri yaitu 0,2 mg/m3. Indikator paparan debu pada manusia berupa keluhan-keluhan pernafasan.Keluhan-keluhan pernafasan yang sering dialami oleh pekerja atau orang yang berada atau terpapar debu antara lain keluhan batuk, sesak nafas, dahak, sesak nafas dengan mengi/bengek. Keluhan-keluhan tersebut dipengaruhi oleh beberapa faktor, yaitu :

Lama paparan partikel debu berpotensi untuk membantu terjadinya PPOM (Penyakit Paru Obstruktif Menahun). 
Secara kronis paparan debu akan mengganggu mukosa penglihatan dan menyebabkan terjadinya iritasi kulit. Selain itu juga dapat menyebabkan peningkatan prevalensi bronchitis kronis, dan menyebabkan penurunan fungsi paru, yang kedua faktor tersebut merupakan predisposisi untuk terjadinya PPOM. (Mukono, 2008, h.126).

Undang-Undang No.1 tahun 1970 tentang keselamatan kerja, pasal12 mengatur mengenai hak dan kewajiban tenaga kerja untuk memakai alat pelindung diri.Perlindungan tenaga kerja melalui usaha-usaha teknis pengamanan tempat, peralatan dan lingkungan kerja sangat perlu diutamakan.Namun terkadang bahaya masih belum dapat dikendalikan sepenuhnya sehingga diperlukan penggunaan alat-alat pelindung diri (Personal Protective Devices).Alat-alat pelindung diri faktor bahaya debu untuk bagian alat pernafasan berupa respirator/masker khusus.(Suma'mur, 1994, h. 218).

Respirator dengan filter debu, merupakan masker yang menggunakan filter yang telah dimuati medan magnet sehingga dapat menyaring partikel debu dan juga dapat dibersihkan dengan air mengalir ataupun ditepuk-tepuk sehingga debu terlepas. (J.M Harrington dan F.S Gill, 2003, h. 255).

Ada beberapa macam dampak yang ditimbulkan oleh debu debu yang masuk ke dalam yang masuk ke dalam tubuh melalui saluran pernafasan, salah satunya ialah menimbulkan penyakit yang disebabkan oleh debu. Menurut Depkes RI (Pedoman Hiperkes, 1990, h. 25) ada berbagai macam penyakit yang disebabkan oleh debu antara lain :

Silicosis, yaitu penyakit yang disebabkan karena debu yang mengandung silica bebas, yang biasanya mengenai para pekerja yang bekerja pada perusahaan yang menghasilkan silikat batuan untuk bangunan, perusahaan keramik dan lain-lain. Sumber lain yang banyak ditemukan debu silica adalah pada perusahaan tegel, keramik, pabrik semen, tambang timah putih (bukan karena timah putihnya), tambang batu bara (bukan oleh batu baranya), dan lain-lain.

Masa timbulnya inkubasi silicosis adalah 2-4 tahun, tergantung pada dosis/ kadar silika bebas dalam debu yang telah terhirup. Gejalanya adalah sesak nafas, makin berat tingkatnya, semakin parah sesaknya.

Asbetosis, yaitu penyakit yang disebabkan oleh debu asbes dan biasanya terkena pada pekerja yang bekerja pada pengolahan asbs.Gejalanya berupa sesak nafas, batuk dengan banyak dahak dan tubuh kelihatan pucat.

Berylosis, adalah penyakit yang disebabkan oleh berrylium yang berupa logam, oksida, sulfat klorida, fluoride, dapat menyebabkan bronchitis dan pneumoconiosis.

Byssinosis, yaitu penyakit yang disebabkan oleh debu kapas, dan biasanya terjadi pada pekerja yang bekerja pada perusahaan tekstil.Masa inkubasi penyakit rata-rata adalah 5 tahun.

Antrakosis, Yaitu penyebab utama penyakit ini adalah debu arang batu pada berbagai sumber tambang arang batu.

Stanosis, adalah penyakit yang disebabkan karena terlalu banyak menghirup timah putih.

Siderosis, adalah penyakit yang disebabkan oleh debu yang mengandung besi dan umumnya terjadi pada pekerja pada perusahaan yang mengolah biji besi.

Talcosis, Adalah penyakit yang disebabkan oleh karena debu talk yang masuk ke dalam paru-paru, di mana biasanya talk ini merupakan campuran mineral-mineral dan tidak hanya magnesium silika saja. Penyakit ini pada umumnya terjadi pada pekerja-pekerja perusahaan kosmetik, cat pembuatan kertas, powder dan lain-lain.

Pengaruh pencemar debu terhadap alat-alat pernafasan tergantung pada sifat fisis, kimia, maupun fisologis. Menurut Slamet Ryadi (1982, h.70), ada 4 alternatif pengaruh fisis terhadap partikel debu, yaitu :

Debu yang memiliki ukuran $5 \mu$ atau lebih akan ikut jatuh sejalan dengan percepatan gravitasi dan bila terhirup melalui pernafasan biasanya lebih banyak jatuh pada alat pernafasan bagian atas sehingga memberikan gangguan berupa iritasi yaitu pharyngitis yang mudah diobati.

Debu yang berukuran 3-5 $\mu$ akan jatuh lebih ke arah dalam yaitu pada saluran pernafasan. Hanya bedanya disini lebih banyak memiliki aspek pathologis yaitu menimbulkan penyakit-penyakit bronchitis, allergi atau asthma.

Debu yang berukuran 1-3 $\mu$ akan jatuh lebih dalam lagi sampai pada alveoli. Debu-debu ini karena sudah mengadakan hambatan terhadap fungsi alveoli sebagai media pertukaran gas zat asam/asam arang, maka dengan melekatnya debu-debu dengan ukuran ini pada alveoli akan memberikan gangguan terhadap kemampuan proses pertukaran gas.

Debu yang mempunyai ukuran $0,1-1,0 \mu$, karena sangat kecil dan tidak memiliki berat ternyata tidak dapat menempel pada permukaan alveoli, tetapi mengikuti gerakan Brown dan berada dalam bentuk suspensi.

Menurut Slamet Ryadi (1982, h.72), terhadap adanya debu di dalam alat pernafasan, maka tubuh dapat memberikan berbagai reaksi, yaitu :

Pada debu yang menetap pada lokasi saluran pernafasan atas akan memberikan reaksi iritasi dengan akibat yang dapat ditimbulkan berupa pharyngitis. Reaksi yang timbul untuk mengeluarkan debu adalah refleks batuk, yang lama-lama debu dapat keluar bersama dengan keluarnya riak.

Debu-debu yang sudah berada dalam jaringan paruparu lama-lama semakin banyak yang tertimbun akan menimbulkan suatu penyakit yang disebut 
pneumoconiosis, yaitu penyakit paru-paru dimana tertimbunnya debu-debu.

Partikel debu akan berada di udara dalam kurun waktu yang relatif lama dalam keadaan melayanglayang di udara kemudian masuk ke dalam tubuh manusia melalui pernafasan. Selain dapat membahayakan terhadap kesehatan juga dapat mengganggu daya tembus pandang mata dan dapat mengadakan berbagai reaksi kimia sehingga komposisi debu di udara menjadi pertikel yang sangat rumit karena merupakan campuran dari berbagai bahan dengan ukuran dan bentuk yang relatif berbeda-beda (Pujiastuti, 2002).

Ada tiga cara masuknya bahan polutan seperti debu dari udara ke tubuh manusia, yaitu melalui inhalasi, ingesti, dan penetrasi kulit. Inhalasi bahan polutan dari udara dapat menyebabkan gangguan di paru dan saluran nafas.Bahan polutan yang cukup besar tidak jarang masuk ke saluran cerna.Selain itu juga batuk merupakan suatu mekanisme untuk mengeluarkan debudebu tersebut. Bahan polutan dari udara juga dapat masuk ketika makan atau masuk ke saluran cerna. Bahan polutan dari udara juga dapat menjadi pintu masuk bahan polutan di udara, khusunya bahan organik dapat melakukan dan dapat menimbulkan efek sistemik (Aditama, 1992).

Beberapa faktor berpengaruh dalam timbulnya penyakit atau gangguan akibat paparan debu bagi pekerja di ruang kerja. Menurut Yunus (1997) dan Suma'mur (1996), dapat disimpulkan bahwa faktor yang mempengaruhi timbulnya gangguan atau penyakit akibat pekerja yang bekerja di ruangan akibat paparan debu adalah :

Faktor fisik, meliputi : Jenis bahan, Ukuran Partikel, Bentuk Partikel, Daya penetrasi, Konsentrasi, Daya larut, Luas permukaan (Higroskopisitas), Lama waktu paparan dan Turbulensi udara.

Faktor kimia, meliputi : Tingkat keasaman dan kebasahan (Alkalinitas), Kecendrungan untuk bereaksi dengan bahan dalam paru-paru, dan jenis persenyawaan. Faktor individual pekerja, meliputi : Umur, Jenis Kelamin, Anatomi dan fisiologi, Daya tahan tubuh (Immunologis), Genetik, dan Emosi (Psikologis), Keadaan gizi, Kepekaan tubuh, Motivasi kerja dan pengaruh lingkungan (Habituasi).

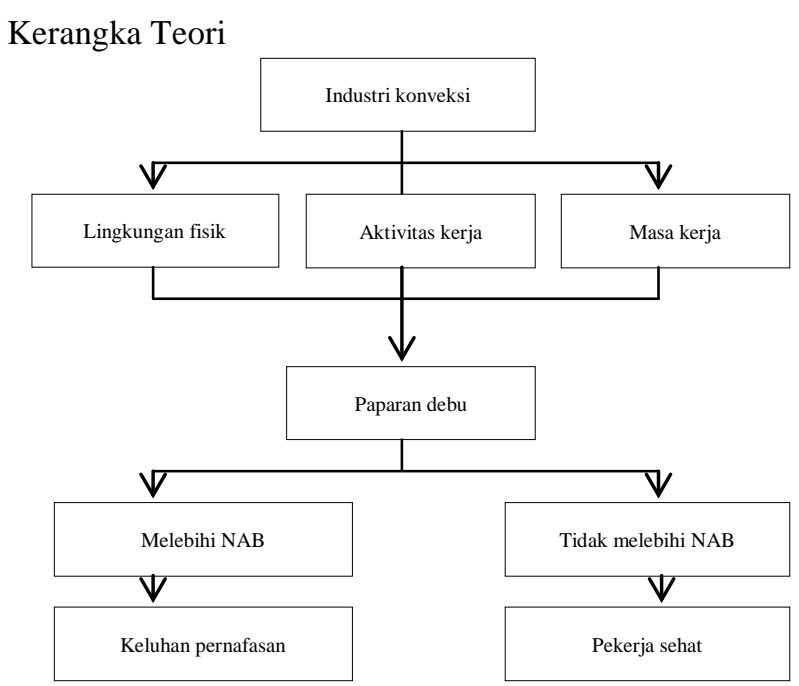

Bahan dan Metode: Jenis penelitian yang digunakan adalah observasional dengan pendekatan crossectional study. Uji statistik yang digunakan adalah regresi logistik

Variabel bebas dalam penelitian ini adalah paparan debu dan masa kerja, variabel terikat dalam penelitian ini adalah keluhan pernafasan, variabel pengganggu dalam penelitian ini adalah umur, riwayat penyakit pernafasan, kecepatan angin, suhu, kelembaban, dan kebiasaan merokok.

Struktur hubungan variabel

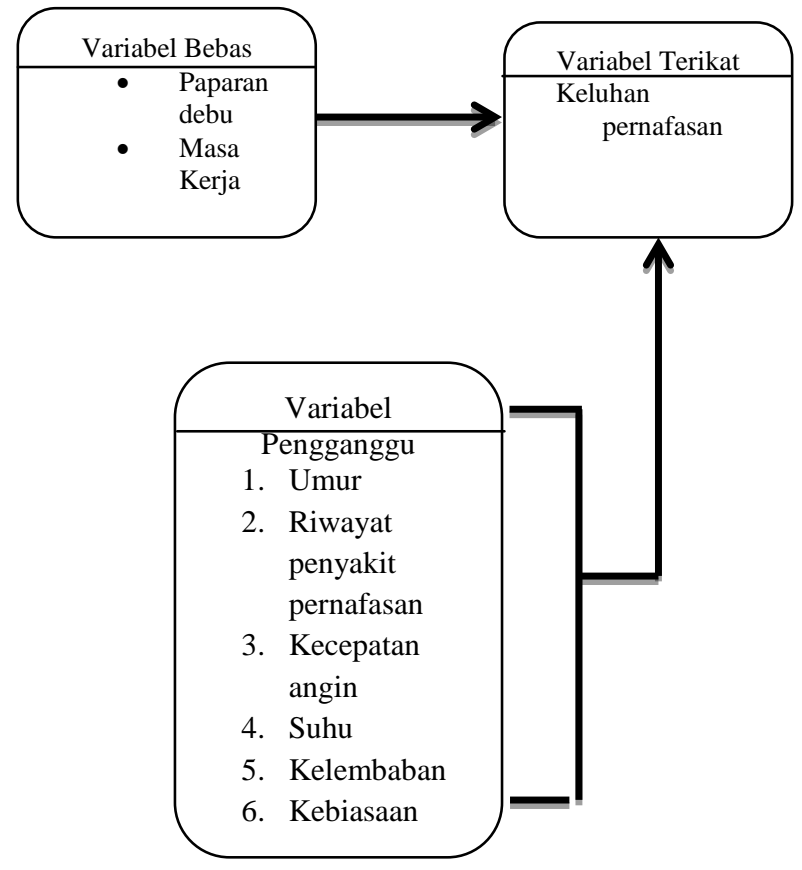

Waktu penelitian pada persiapan sampai penyelasaian dilakukan bulan Oktober 2016 - Juni 2017.Lokasi yang digunakan dalam penelitian ini yaitu 
di Desa Notog, Kecamatan Patikraja Kabupaten Banyumas.

Populasi dalam penelitian ini adalah pekerja yang bekerja di CV. Jiyog's Konveksi terdapat 20 orang. Tehnik pengambilan sampel pada tenaga kerja CV. Jiyo'g Konveksi menggunakan sampling jenuh dengan kriteria inklusi yaitu laki-laki sebanyak 10 orang, tenaga kerja berumur 20-40 tahun, dan memiliki masa kerja $\geq 3$ tahun.

Cara pengumpulan data: Melaksanakan observasi dengan melakukan pengamatan langsung terdapat objek yang diteliti dilingkungan kerja CV. Jiyog's Konveksi. Data observasi meliputi : kondisi perilaku pekerja, upaya pengendalian resiko paparan debu dari proses kerja pada para pekerja di CV. Jiyog's Konveksi.Pembagian kuesioner dilakukan untuk memperoleh informasi yang dibutuhkan oleh penelitian dalam penyusunan skripsi kepada pekerja di CV. Jiyog's Konveksi Notog. Data meliputi: keluhan pernafasan, masa kerja, APD yang disediakan CV. Jiyog's Konveksi, upaya meminimalisir dampak pemaparan kadar debu pada pekerja. Dilakukan wawancara dengan melakukan kegiatan tanya jawab secara langsung pada responden atau pekerja CV. Jiyog Konveksi menggunakan kuesioner.Yaitu pengumpulan data dengan cara melakukan pengukuran objek yang ingin diketahui ukurannya, yaitu paparan debu.Mengetahui kondisi lingkungan pada Industri Jiyog's Konveksi. Data meliputi : penggunaan APD pada pekerja.

Instrument pengumpulan data :Kuesioner untuk mengkaji waawancara dengan responden.Personal Dust Sampler untuk mengukur paparan debu dari sumber debu terhadap responden.Anemometer untuk mengukur kecepatan angin.Thermo/Higrometer untuk mengukur suhu dan kelembaban.Checklist untuk mengkaji wawancara dengan responden.

Hasil dan Pembahasan: Penelitian ini diharapkan terdapat hubungan yang signifikan antara paparan debu dan masa kerja dengan keluhan pernafasan, dan terdapat resiko peningkatan antara variabel bebas dan variabel terikat. Penelitian ini dilakukan dengan pendekaan cros-sectioanal dilaksanakan pada waktu yang bersamaan di hari yang sama.Kegiatan penelitian ini meliputi pengukuran paparan debu menggunakan PDS/ Dusttrak, pengukuran suhu dan kelembaban, pengukuran kecepatan angin menggunakan anemometer, pembagian kuesioner, dan wawancara terhadap responden.

\begin{tabular}{|c|c|c|c|c|c|c|c|c|c|}
\hline \multirow[b]{2}{*}{ No } & \multirow[b]{2}{*}{$\underset{\mathrm{a}}{\mathrm{Nam}}$} & \multirow{2}{*}{$\begin{array}{c}\text { Jenis } \\
\text { Kelami } \\
\mathrm{n}\end{array}$} & \multirow[b]{2}{*}{$\underset{r}{\mathrm{r} u}$} & \multirow{2}{*}{$\begin{array}{l}\text { Tingg } \\
\mathrm{i} / \mathrm{bb} \\
(\mathrm{cm} / \\
\mathrm{kg})\end{array}$} & \multicolumn{2}{|c|}{$\begin{array}{c}\text { Keluhan } \\
\text { Pernafasan }\end{array}$} & \multirow{2}{*}{$\begin{array}{l}\text { Papara } \\
\text { n Debu } \\
\left(\mathrm{mg} / \mathrm{m}^{3}\right. \\
)\end{array}$} & \multicolumn{2}{|c|}{$\begin{array}{l}\text { Riwayat Penyakit } \\
\text { Pernafasan }\end{array}$} \\
\hline & & & & & $\begin{array}{l}\text { Perna } \\
\text { h }\end{array}$ & $\begin{array}{l}\text { Tidak } \\
\text { Perna } \\
\text { h }\end{array}$ & & $\begin{array}{l}\text { Perna } \\
\text { h }\end{array}$ & $\begin{array}{l}\text { Tidak } \\
\text { Perna } \\
\text { h }\end{array}$ \\
\hline 1. & A & L & 46 & 168 & $\checkmark$ & & 0,070 & & $\checkmark$ \\
\hline 2. & B & L & 48 & 170 & & $\checkmark$ & 0,145 & & $\checkmark$ \\
\hline 3. & c & L & 38 & 169 & & $\checkmark$ & 0,073 & & $\checkmark$ \\
\hline 4. & D & L & 29 & 168 & & 。 & 0,060 & & $\checkmark$ \\
\hline 5. & E & L & 47 & 160 & $\checkmark$ & & 0,051 & $\checkmark$ & \\
\hline 6. & $\mathrm{~F}$ & L & 30 & 171 & & $\checkmark$ & 0,069 & & $\checkmark$ \\
\hline 7. & G & L & 38 & 172 & $\checkmark$ & & 0,041 & $\checkmark$ & \\
\hline 8. & $\mathrm{H}$ & L & 40 & 172 & & $\checkmark$ & 0,036 & & $\checkmark$ \\
\hline 9. & 1 & L & 35 & 163 & & $\checkmark$ & 0,045 & & $\checkmark$ \\
\hline 10 & $\mathrm{~J}$ & L & 46 & 166 & & & 0,073 & & \\
\hline
\end{tabular}

Jumlah pekerja yang ada di CV. Jiyo'g Konveksi

Desa Notog Kecamatan Patikraja Kabupaten Banyumas sebanyak 20 orang terdiri dari 10 perempuan dan 10 laki-laki, jumlah responden yang diambil sebagai bahan penelitian yaitu laki-laki sebanyak 10 responden. Para pekerja di CV. Jiyo'g Konveksi rata-rata berusia 29-48 tahun yang memiliki jenis kelamin laki-laki.Gambaran mengenai pekerja CV. Jiyo'g Konveksi Desa Notog Kecamatan Patikraja Kabupaten Banyumas menurut umur dan jenis kelamin.

Hasil pengukuran paparan debu terhadap responden di CV. Jiyo'g Konveksi

\begin{tabular}{ccc}
\hline No. & Nama & Paparan Debu $\left(\mathrm{mg} / \mathrm{m}^{3}\right)$ \\
\hline 1. & A & 0.070 \\
2. & B & 0.145 \\
3. & C & 0.073 \\
4. & D & 0.060 \\
5. & E & 0.051 \\
6. & F & 0.069 \\
7. & G & 0.041 \\
8. & H & 0.036 \\
9. & I & 0.045 \\
10. & J & 0.073 \\
\hline \multicolumn{2}{c}{ Rata-rata } & 0,066 \\
\hline \multicolumn{2}{c}{ Paparan }
\end{tabular}

responar para nomor debu terkecil yaitu $\mathrm{mg} / \mathrm{m} 3$. Rata-rata paparan debu pada responden yaitu sebesar $0,066 \mathrm{mg} / \mathrm{m} 3$.

Hasil pengukuran paparan debu pada responden, menggunakan Dusttrak diperoleh kadar debu maksimum sebesar $0,154 \mathrm{mg} / \mathrm{m}^{3}$ dan kadar debu minimal sebesar $0,036 \mathrm{mg} / \mathrm{m}^{3}$. Berdasarkan Peraturan Tenaga Kerja dan Transmigrasi Republik indonesia Nomor Per.13/ Men/ X/ 2011 tentang Faktor Fisika dan Faktor Kimia di Tempat Kerja, ditetapkan NAB debu di area tempat pekerja adalah $5 \mathrm{mg} / \mathrm{m}^{3}$, sedangkan berdasarkan Permenkes RI Nomor. 70 Tahun 2016 tentang Standar 
dan Persyaratan Kesehatan Lingkungan Kerja Industri, yaitu untuk standar debu kapas/ katun sebesar 0,2 $\mathrm{mg} / \mathrm{m} 3$.

semua responden yang telah dilakukan pengukuran paparan debu menggunakan dusttrak memenuhi syarat, ini dikarenakan saat dilakukan penelitian pekerjaan tidak dilakukan secara maksimal, karena perusahaan tidak sedang mengejar target, dan karyawan yang berangkat hanya beberapa, pengaruh banyaknya debu-pun berkurang. Pada saat pengukuran hampir melebihi NAB debu katun namun pada kategori max pada responden $B$, yaitu sebesar $0,599 \mathrm{mg} / \mathrm{m} 3$ yaitu pada pekerja bagian pemotongan bahan. Menurut J. Jeyaratman dan David Koh (2009, h. 65), faktor pekerja atau lingkungan yang merupakan etiologi utama, baik sebagai penyebab utama maupun penyebab tambahan harus diidentifikasi untuk menangani kasus secara tepat.Pekerja bekerja sebagai operator yang bertugas dalam produksi di seluruh area industri, sehingga terdapat paparan yang stabil. Faktor lain yang mempengaruhi tingginya kadar debu yang diperoleh yaitu waktu pengukuran pengujian paparan debu. Waktu pengukuran pengujian paparan debu yang digunakan yaitu 15 menit, tetapi dalam waku 15 menit di area pemotongan bahan pekerjaannya tidak maksimal sehingga paparan debu yang dikeluarkan tidak konstan maksimal terus menerus.

Distribusi masa kerja pada tenaga kerja CV. Jiyo'g Konveksi

\begin{tabular}{ccc}
\hline No. & Nama Responden & $\begin{array}{c}\text { Masa Kerja } \\
\text { (Tahun) }\end{array}$ \\
\hline 1. & $\mathrm{~A}$ & 20 \\
2. & $\mathrm{~B}$ & 10 \\
3. & $\mathrm{C}$ & 15 \\
4. & $\mathrm{D}$ & 3 \\
5. & $\mathrm{E}$ & 20 \\
6. & $\mathrm{~F}$ & 10 \\
7. & $\mathrm{G}$ & 10 \\
8. & $\mathrm{H}$ & 15 \\
9. & $\mathrm{I}$ & 10 \\
10. & $\mathrm{~J}$ & 10 \\
\hline
\end{tabular}

Tabel diatas menunjukkan bahwa masa kerja pada responden yang paling lama bekerja yaitu nomor reponden 1 yaitu memiliki masa kerja 20 tahun, dan responden dengan kriteria masa kerja terpendek yaitu 3 tahun. Rata-rata untuk masa kerja pada responden yaitu 12,3 tahun.Semakin lama masa kerja, semakin lama pula tenaga kerja tersebut terpapar debu kapas, sehingga semakin banyak paparan debu kapas yang tertimbun dalam paru yang nantinya akan mempengaruhi kapasitas fungsi paru. Sebuah gangguan manifestasi klinik dari penurunan fungsi pernafasan akan mulai terlihat dan menjadi permanen setelah terpajan debu antara $10-20$ tahun bekerja (Faisal, 1997).

Hasil wawancara keluhan pernafasan terhadap responden menggunakan kuesioner

\begin{tabular}{cccc}
\hline No. & Kategori & Frekuensi & $\begin{array}{c}\text { Persentase } \\
(\%)\end{array}$ \\
\hline 1 & $\begin{array}{r}\text { Tidak } \\
\text { pernah } \\
2\end{array}$ & 7 & 70 \\
Pernah & 3 & 30 \\
\hline
\end{tabular}

Berdasarkan data yang diperoleh dari responden sebanyak 10 orang, yang didapatkan dari hasil pengisian kuesioner didapatkan untuk katagori tidak terdapat keluhan pernafasan terdapat 7 orang (70\%), katagori terdapat keluhan pernafasan sebanyak 3 orang (30\%). Dilihat dari hasil rekapitulasi menyimpulkan bahwa kebanyakan pekerja bagian penyablonan yang terdapat gangguan keluhan pernafasan karena terdapat aliran udara dari luar yang masuk ke dalam perusahaan, sehingga menimbulkan debu berterbangan masuk, dan juga efek bau menyengat dari bahan sablon, seperti cat dan masih banyak lagi.

Dampak pencemaran udara terutama terhadap organ tubuh yaitu alat pernafasan, mulai dari hidung, tenggorokan sampai paru-paru memiliki fungsi sendiri-sendiri yang menyaring debu masuk ke dalam tubuh. Apabila dari organ pernafasan ini sudah tidak berfungsi dengan baik untuk menyaring debu yang masuk ke dalam tubuh, maka akan mengakibatkan adanya gangguan pernafasan sampai dengan merusak paru-paru (Mangku, 1997, h. 35). Adanya keluhan pernafasan pada pekerja bagian repair dapat dilihat dari kebiasaan menggunakan alat pelindung, diri seperti; masker yang jarang digunakan bahkan tidak menggunakan, adanya debu katun/ kapas yang dihirup secara terus menerus dan kebiasaan merokok pekerja.

Hasil pengukuran suhu di CV. Jiyo'g Konveksi menggunakan thermo/ hygro.

\begin{tabular}{clc}
\hline No. & \multicolumn{1}{c}{ Statistik } & $\begin{array}{c}\text { Suhu } \\
\left({ }^{\circ} \mathrm{C}\right)\end{array}$ \\
\hline 1. & Rata - rata & 28,9 \\
2. & $\begin{array}{l}\text { Standar error dari rata } \\
\text { - rata }\end{array}$ & 0,23 \\
3. & Median & 29 \\
4. & Standar deviasi & 0,37 \\
5. & Suhu terendah & 28 \\
6. & Suhu tertinggi & 30 \\
\hline
\end{tabular}


Berdasarkan Permenkes RI Nomor. 70 Tahun 2016 tentang Standar dan Persyaratan Kesehatan Lingkungan Kerja Industri suhu ruangan sebesar 27,5 $32,5^{\circ} \mathrm{C}$. Berdasarkan tabel 4.4 diketahui bahwa suhu terendah di ruang pekerja sebesar $28^{\circ} \mathrm{C}$, sedangkan suhu tertinggi mencapai $30^{\circ} \mathrm{C}$ dengan rata-rata suhu $28,9^{\circ} \mathrm{C}$. Kondisi tersebut disebabkan oleh cuaca yang cukup panas di lingkungan kerja.

Suhu merupakan faktor yang membentuk cuaca kerja, selain faktor kecepatan angin dan suhu radiasi.Faktor inilah yang turut mempengaruhi kenyamanan tenaga kerja saat berada di lingkungan kerja (Suma'mur, 2009). Suhu yang tinggi akan mempercepat terjadinya perubahan kadar gas atau polutan di udara. Semakin tinggi suhu udara, maka partikel akan menjadi semakin kering dan ringan. Suhu yang tinggi juga menyebabkan partikel lebih reaktif dan dapat bertahan lebih lama di udara, sedangkan suhu yang rendah dapat mengganggu kenyamanan dalam bekerja (Salisa, 2011).

H.J Mukono (1997) juga berpendapat bahwa suhu tinggi dapat menyebabkan udara dalam ruangan menjadi kering atau sangat sedikit mengandung air, sehingga tidak mengikat polutan berupa debu. Polutan akan melayang-layang lebih lama di udara, sehingga konsentrasi pencemaran akan semakin tinggi, sedangkan suhu udara yang menurun dapat menyebabkan kelembaban udara relatif, sehingga akan meningkatkan kecepatan reaksi suatu bahan kimia. Perlu penambahan ventilasi pada tempat kerja yang luasnya 15\% dari luas lantai.

Hasil pengukuran kelembaban di CV. Jiyo’g

\begin{tabular}{|c|c|c|}
\hline No. & Statistik & $\begin{array}{c}\text { Kelembaban } \\
(\%)\end{array}$ \\
\hline 1. & Rata - rata & 63,7 \\
\hline 2. & $\begin{array}{l}\text { Standar error } \\
\text { dari rata - rata }\end{array}$ & 0,3 \\
\hline 3. & Median & 64,0 \\
\hline 4. & Standar deviasi & 0,95 \\
\hline 5. & $\begin{array}{l}\text { Kelembaban } \\
\text { terendah }\end{array}$ & 62,0 \\
\hline 6. & $\begin{array}{l}\text { Kelembaban } \\
\text { tertinggi }\end{array}$ & 65,0 \\
\hline
\end{tabular}

Persyaratan kelembaban ruangan berdasarkan Permenkes RI Nomor.70 Tahun 2016 tentang Standar dan Persyaratan Kesehatan Lingkungan Kerja Industri adalah sebesar 65-95 \%. Kelembaban terendah di ruang kerja 62\%, sedangkan kelembaban tertinggi sebesar 65\% dengan rata-rata kelembaban sebesar 63,7\%. Secara umum kelembaban di ruang kerja tidak memenuhi syarat, rendahnya kelembaban udara sangat dipengaruhi oleh tingginya suhu pada penelitian dilakukan, serta penelitian dillakukan pada musim kemarau hal tersebut semakin mempengaruhi tingginya suhu. Sehingga dapat mempengaruhi penyebaran volume debu diudara. Perlu

penambahan ventilasi pada ruang kerja yang luasnya $15 \%$ dari luas lantai.

Hasil tabulasi umur pada responden yang bekerja di CV. Jiyo'g Konveksi.

\begin{tabular}{clc}
\hline No. & \multicolumn{1}{c}{ Statistik } & Umur \\
\hline 1 & Rata-rata & 39.70 \\
2 & Standar error dan & 2.206 \\
3 & rata-rata & Median \\
4 & Standar deviasi & 6.977 \\
5 & Umur Terendah & 29 \\
6 & Umur Tertinggi & 48 \\
\hline
\end{tabular}

Rata-rata umur 10 responden adalah 39,7 tahun, dengan data terendah dari umur responden adalah 29 tahun dan data tertinggi dari umur responden adalah 48 tahun. Keluhan pernafasan dialami oleh responden yang berumur 29-47 tahun terdapat 3 orang. Meskipun ratarata responden yang memiliki keluhan pernafsan hanya 30\% dari 10 responden, akan tetapi hasil ini semakin mengkuatkan penelitian Sholihah, dkk. (2008) yang menyatakan pekerja berusia 15-30 lebih banyak yang mengalami keluhan pernafasan. Hasil ini sesuai dengan teori yang menyatakan semakin tua usia seseorang, maka resiko untuk mengalami penyakit pernafasan semakin besar. Hal ini berhubungan dengan kemampuan organ tubuh yang mengalami penurunan seiring dengan peningkatan usia (Irjayanti, dkk., 2012).

Hasil wawancara riwayat pernafasan terhadap responden

\begin{tabular}{clcc}
\hline No. & Kategori & $\begin{array}{c}\text { Frekuen } \\
\text { si }\end{array}$ & $\begin{array}{c}\text { Persen } \\
(\%)\end{array}$ \\
\hline 1. & $\begin{array}{l}\text { Tidak } \\
\text { pernah }\end{array}$ & 8 & 80 \\
2. & Pernah & 2 & 20 \\
\hline
\end{tabular}

Menurut Suma'mur (2009) anamnesis tentang riwayat penyakit dimaksudkan untuk mengetahui kemungkinan salah satu faktor di tempat kerja, pada pekerjaan atau lingkungan kerja menjadi penyebab penyakit paru akibat kerja.

Hasil penelitian terhadap 10 responden 2 responden memiliki riwayat penyakit pernafasan berupa penyakit ISPA.Orang yang memiliki riwayat penyakit pernafasan mempunyai risiko yang lebih tinggi terkena gangguan keluhan pernafasan (J.Jeyaratnam dan David koh, 2009, h. 65).Salah satu pencegahan untuk mengurangi paparan debu yang masuk ke paru-paru dengan menghindari diri dari debu dan memakai alat 


\begin{tabular}{|c|c|c|c|c|}
\hline No. & Jenis Variabel & $\alpha$ & $\mathrm{p}$ & PR \\
\hline Nb. & Paparan Błghtst & 0,05 & 0,459 & $\begin{array}{l}\text { Keçp:otad } \\
\text { angin }(\mathrm{m} / \mathrm{s})\end{array}$ \\
\hline R. & Raktasaraterja & 0,05 & 0,129 & 0,39264 \\
\hline 2. & \multicolumn{3}{|c|}{ Standar error dari rata - rata } & 0,0467 \\
\hline 3. & \multicolumn{3}{|c|}{ Median } & 0,250 \\
\hline 4. & \multicolumn{3}{|l|}{ Standar deviasi } & 0,147 \\
\hline 5. & \multicolumn{3}{|c|}{ Kecepatan angin terendah } & 0,2 \\
\hline 6. & \multicolumn{3}{|c|}{ Kecepatan angin tertinggi } & 0,6 \\
\hline
\end{tabular}

pelindung diri berupa masker dengan pori-pori tertentu selama berada di tempat kerja. Konveksi

Hasil pengukuran kecepatan angin di CV. Jiyo'g

Kecepatan aliran udara tertinggi yaitu $0,6 \mathrm{~m} / \mathrm{s}$, dan terendah adalah $0,2 \mathrm{~m} / \mathrm{s}$, dengan rata-rata kecepatan angin $0,32 \mathrm{~m} / \mathrm{s}$, sedangkan menurut Permenkes RI Nomor. 70 Tahun 2016 tentang Standar dan Persyaratan Kesehatan Lingkungan Kerja Industri untuk kecepatan angin sebesar 0,15 - 0,25 m/s, maka secara umum kecepatan aliran udara tidak memenuhi syarat yang ditentukan. Hal ini dipengaruhi adanya ruang pintu ruang proses penyablonan selalu terbuka dan berdekatan dengan jalan ranya, yang menyebabkan aliran udara dari luar industri dapat masuk ke dalam industri.

\begin{tabular}{cccc}
\hline No. & Kategori & Frekuensi & Presentase (\%) \\
\hline 1. & Tidak merokok & 3 & 30 \\
2. & Merokok & 7 & 70 \\
\hline Upaya yang dapat & dilakukan & adalah dengan \\
menambah ventilasi udara, memasang exshauster, atau \\
kipas blower. \\
$\begin{array}{c}\text { Hasil tabulasi kebiasaan merokok responden di } \\
\text { CV. Jiyo'g Konveksi }\end{array}$
\end{tabular}

Hasil penelitian didapatkan 7 responden (A, D, E, F, G, H, dan I) merokok dan 3 responden (responden B, C, dan J) tidak merokok. Orang yang merokok akan memiliki kecenderungan lebih besar untuk terkena penyakit paru/ gangguan pernafasan dibandingkan orang yang tidak merokok. Suatu pencegahan yang sangat umum dilakukan adalah larangan merokok, khususnya di tempat kerja atau dimulai sejak memasuki halaman perusahaan.(Suma'mur, 1997, hal 55).

Hasil uji statistik menggunakan regresi logistik antara Paparan Debu dan Masa Kerja dengan Keluhan Pernafasan.
Hubungan antara paparan debu dengan keluhan pernafasan menggunakan uji regresi logistik untuk mengetahui ada tidaknya hubungan tersebut. Berdasarkan hasil uji statistik diperoleh nilai p $(0,459)$ lebih besar dari $\alpha(0,05)$ maka Ha ditolak $\mathrm{H} 0$ diterima. Nilai PR (Prevalence Ratio) paparan debu 0,000 menunjukkan bahwa paparan debu tidak meningkatkan resiko terjadi keluhan pernafasan.

Hubungan antara masa kerja dengan keluhan pernafasan menggunakan uji regresi logistik untuk mengetahui ada tidaknya hubungan tersebut. Berdasarkan hasil uji statistik diperoleh nilai p $(0,129)$ lebih besar dari $\alpha(0,05)$, maka Ha ditolak Ha diterima. Nilai PR (Prevalence Ratio) masa kerja 0,904 menunjukkan bahwa masa kerja tidak meningkatkan resiko terjadi keluhan pernafasan.

Hasil penelitian diinterprestasikan bahwa tidak ada hubungan paparan debu dan masa kerja dengan keluhan pernafasan pada pekerja di CV. Jiyo'g Konveksi Notog Kabupaten Banyumas. Debu bukan satu-satunya penyebab terjadinya keluhan pernafasan pada pekerja. Akan tetapi tidak menutup kemungkinan keluhan pernafasan pada responden diakibatkan oleh faktor-faktor yang tidak dapat dikendalikan peneliti yaitu riwayat penyakit pernafasan, kebiasaan merokok. Keadaan ini tidak mempunyai pengaruh yang besar terhadap keluhan pernafasan dibandingkan dengan keadaan yang telah diuraikan diatas.Pengaruh faktor luar dapat mempengaruhi keluhan pernafasan pada pekerja. Kesalahan pengukuran juga dapat terjadi dalam penelitian ini, antara lain pekerja tidak seluruhnya bekerja sesuai dengan target dikarenakan industri sedang tidak ada orderan. Keterbatasan penelitian saat dilakukan pengukuran paparan debu menggunakan dusttrak masih belum maksimal.

Hasil penelitian ini sama dengan penelitian Jaenuri (2011) menunjukan hasil analisis statistik menggunakan uji statistik regresi logistik tidak ada hubungan antara kadar debu dan lama paparan dengan kejadian ISPA pada petugas pos lantas Kota Purbalingga, dikarenakan nilai signifikasi dari kedua variable bebas tersebut melebihi nilai $\mathrm{p}(\operatorname{sig}) \alpha=0,05$.

Cakupan dari masalah debu diatas, pencegahan terutama sangat penting dalam usaha mengurangi pemasalahan debu di tempat kerja. Menurut Suma'mur(1996) dan Budiono (2003) beberapa upaya preventif tersebut antara lain adalah:

Ventilasi umum, dengan mengalirkan udara ke dalam ruang kerja.

Pemakaian masker, dilihat dari fungsinya masker merupakan APD yang mengambil peran penting dalam mengurangi jumlah debu perseorangan.

Pemeriksaan kesehatan berkala, merupakan satu tindakan preventif yang ditujukkan supaya karyawan yang mengidap gangguan paru dapat dideteksi secara 
dini dan dapat ditangani secara intensif menurut Suma'mur (1996) dan Budiono (2003).

Kesimpulan dan Saran:Berdasarkan hasil dan pembahasan tentang hubungan paparan debu dan masa kerja dengan keluhan pernafasan pada tenaga kerja CV. Jiyo'g Konveksi, dapat disimpulkan bahwa :

Berdasarkan hasil pengukuran paparan debu pada tenaga kerja di CV. Jiyo'g Konveksi terdapat 1 responden yang memiliki paparan debu terbesar yaitu 0,145 mg/m3, dan dibandingkan dengan Permenkes RI Nomor. 70 Tahun 2016 tentang Standar dan Persyaratan Kesehatan Lingkungan Kerja Industri untuk standar debu katun/ kapas sebesar 0,2 mg/m3, dikategorikan tidak melebihi NAB.

Berdasarkan hasil penelitian masa kerja didapatkan hasil bahwa masa kerja yang paling lama bekerja yaitu nomor reponden 1 , yaitu memiliki masa kerja 20 tahun, dan responden dengan kriteria masa kerja terpendek yaitu, 3 tahun. Diperoleh rata-rata masa kerja pada tenaga kerja di CV. Jiyo'g Konveksi yaitu 12,3 tahun.

Berdasarkan hasil penelitian keluhan pernafasan pada tenaga kerja CV. Jiyo'g Konveksi dari 10 responden terdapat $3(30 \%)$ responden yang memiliki keluhan pernafasan dan 7 (70\%) orang yang tidak memiliki keluhan pernafasan.

Berdasarkan hasil penelitian suhu dan kelembaban diperoleh rata-rata suhu ruangan 28,9oC dan 63,7 \% untuk kelembaban.

Hasil uji statistik menggunakan regresi logistik didapatkan tidak ada hubungan yang signifikan antara paparan debu dengan keluhan pernafasan $(\mathrm{p}=0,459>$ $\alpha=0,05$ ) Hipotesis yang menyatakan bahwa paparan debu mempunyai hubungan yang signifikan terhadap keluhan pernafasan ditolak. Untuk analisis antara masa kerja dan keluhan pernafasan didapatkan hasil $(\mathrm{p}=0,129$ $>\alpha=0,05)$ yaitu tidak ada hubungan yang signifikan antara masa kerja dan keluhan pernafasan. Hipotesis yang menyatakan bahwa masa kerja mempunyai hubungan yang signifikan terhadap keluhan pernafasan ditolak.

Saran: Menyediakan masker jenis kain untuk pekerja.Perlu pengawasan terhadap pekerja yang tidak memakai masker agar saat bekerja memakai masker, demikian dengan pekerja yang memiliki kebiasaan merokok.Penambahan exshauster diprioritaskan di ruang kerja yang lembab.Sebaiknya membiasakan diri memakai masker sebelum memasuki tempat kerja dan tidak melepas masker pada saat berada di tempat kerja.Sebaiknya pekerja yang memiliki kebiasaan merokok secara berangsur membiasakan diri untuk tidak merokok serta diimbangi dengan perilaku hidup sehat dengan berolahraga dan asupan gizi yang cukup.Perlu dilakukan penelitiaan lebih lanjut dan diharapkan pengukuran keluhan pernafasan menggunakan spirometer, agar data yang dihasilkan lebih valid.Untuk Pengambilan sampel diambil lebih banyak atau keseluruhan pekerja di CV. Jiyo'g Konveksi Notog Kecamatan Patikraja Kabupaten Banyumas.

\section{Daftar Pustaka:}

Aris Santjaka, 2011, Statistik untuk Penelitian Kesehatan, Yogyakarta: Muha medika

A.Tresna Sastrawijaya, 2000, Pencemaran Lingkungan, Jakarta: PT Rineka Citra Departemen Kesehatan R.I. 2003, Modul Pelatihan Bagi Fasilitas Kesehatan Kerja

Anindya Mar'atus Sholikhah, 2015, Hubungan Karakteristik Pekerja dan Kadar Debu Total Dengan Keluhan Pernafasan Pada Pekerja Industri Kayu X di Kabupaten Lumajang, Perspektif Jurnal : Universitas Airlangga

BSN. 2005. Standar Nasional Indonesia SNI 19-02322005 Nilai Ambang Batas (NAB) Zat Kimia di Udara Tempat Kerja. Jakarta.

A.M. Sugeng Budiono. 2003. Bunga Rampai Hiperkes dan Kesehatan Kerja.Semarang : Badan Penerbit UNDIP.

Departemen Kesehatan RI. 1999. Keputusan Menteri Kesehatan RI dan Keputusan Dirjen PPM\&PLP tentang Persyaratan Kesehatan Lingkungan Kerja. Jakarta: Depkes RI.

Depkes R.I., 2003, Lingkungan Hidup dan Pencemaran, Jakarta: Universitas Indonesia

Dewi Yuliati, 2008, "Hubungan Paparan Debu dengan Kapasitas Paru Pekerja Penggilingan Padi "Tani Mulya” di Desa Kalitinggar Kidul Kecamatan Padamara Kabupaten Purbalingga Tahun 2008”, KTI, Purwokerto: Poltekkes Semarang Jurusan Kesehatan Lingkungan

Irjayanti, A., Nurjazuli, \& Suwondo, A. 2012.Hubungan Kadar Debu Terhirup (Respirable) dengan Kapasitas Vital Paksa Paru pada Pekerja Mebel Kayu di Kota Jayapura.Jurnal Kesehatan Lingkungan Indonesia, 11(2), 182- 186. Diakses dari http://www.eprints.undip.ac.id/42542 (sitasi 10 Juli 2014)

Janeuri, 2011, "Hubungan Kadar Debu dan Lama Paparan dengan Kejadian ISPA pada Petugas Satlantas Polres Purbalingga di Pos Lantas Kota Purbalingga Tahun 2011, Skripsi, Purwokerto: Poltekkes Semarang Jurusan Kesehatan Lingkungan.

Jeyaratnam, J., Koh, David. Buku Ajar Praktik Kedokteran Kerja.Jakarta : EGC. 2009.

KEPMENKES. No 1405/MENKES/SK/XI/2002 tentang Persyaratan Kesehatan Lingkugan Kerja Perkantoran dan Industri

Mukono, H.J. 2003, Pencemaran Udara dan Pengaruhnya Terhadap Gangguan Saluran 
Pernafasan, Surabaya: Airlangga University Press

Mukono, H.J, 2008, Pencemaran Udara dan Pengaruhnya terhadap Gangguan Saluran Pernafasan, UNAIR

Mustari Retnawati, 2013, "Hubungan Paparan Debu Degan Kapasitas Paru Pekerja Bagian Raw Mill di PT. HOLCIM INDONESIA Tbk CILACAP PLANT TAHUN 2013”, KTI, Purwokerto: Poltekkes Semarang Jurusan Kesehatan Lingkungan.

Notoatmodjo, Soekidjo. 2010. Metodologi Penelitian Kesehatan. Rinerka Cipta : Jakarta.

Peraturan Menteri Kesehatan Republik Indonesia Nomor 70 Tahun 2016, Tentang Standard an Persyaratan Kesehatan Lingkungan Kerja Industri, 2016

Peraturan Menteri Tenaga Kerja dan Transmigrasi nomor 13 tahun 2011, nilai ambang batas faktor fisik dan faktor kimia tempat kerja

Peraturan Menteri Tenaga Kerja dan Transmigrasi RI Nomor 25 Tahun 2008, Diagnosis Penyakit Akibat Kerja, 2008

Pickett, George dan Hanlon, John J. 2009. Kesehatan Masyarakat : Perlindungan Tenaga Kerja. Jakarta : EGC

Salisa, S. S. 2011. Paparan Asap dari Aktivitas Pengasapan Ikan Terhadap Keluhan Mata, Pernapasan, dan Fungsi Paru (Studi di Jalan Kejawan Lor Kelurahan Kenjeran, Kecamatan Bulak, Surabaya).Skripsi. Fakultas Kesehatan Masyarakat. Universitas Airlangga

Santoso, Singgih. (2015). Menguasai Statistik Multivariat.Jakarta : $\quad$ PT Elex Media Komputindo.

Sholihah, Q., Khairiyati, L., \& Setyaningrum, R. 2008. Pajanan Debu Batubara dan Gangguan Pernapasan pada Pekerja Lapangan Tambang Batubara. Jurnal Kesehatan Lingkungan, 4(2), 1$8 . \quad$ Diakses dari journal.lib.unair.ac.id/index.php/JKL/ar ticle/download/608/605 (sitasi 20 Juni 2014)

Slamet Ryadi, 1982, Pencemaran Udara, Surabaya : Usaha Nasional.

Sufya Akunsari, 2010, Hubungan Antara Paparan Debu Kapas dengan Kejadian Penurunan Kapasitas Fungsi Paru Tenaga Kerja Wanita di PT. DAN LIRIS SUKOHARJO, Surakarta: Universitas Sebelas Maret.

Suma'mur P.K, 1996, Hygiene Perusahaandan Kesehatan Kerja Cetakan keenam, Jakarta: Haji Masagung

Suma'mur, P. K. 2009. Higiene Perusahaan dan Kesehatan Kerja.Cetakan ke sembilan. Jakarta: CV Gunung Agung
Tri Cahyono, 2012, Pedoman Penulisan Proposal Penelitian dan Karya Tulis Ilmiah / Skripsi, Edisi Revisi Kedua, Purwokerto : Kementrian Kesehatan Republik Indonesia Politeknik Kesehatan Kemenkes Semarang Jurusan Kesehatan Lingkungan Purwokerto.

Undang - Undang Republik Indonesia Nomor 36 Tahun 2009, Kesehatan pada Bab XII pasal 164 mengenai Kesehatan Kerja. Jakarta

Undang-undang R.I. No. 36 Tahun 2009, Tentang Kesehatan

Wiwik Pudjiastuti, SKM, 2012, Debu sebagai Bahan Pencemar yang Membahayakan Kesehatan Kerja: Depkes

RI http://www.depkes.go.id/downloads/Udara.PDF, 28 Januari 2014, Pukul 18:20 WIB 